評論及維錄

\title{
地形圖並に文献より見だる千島の火山（3）
}

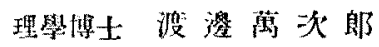

南部千島 $の$ 火山(前)

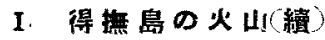

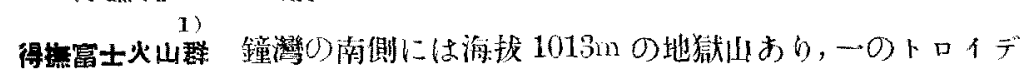

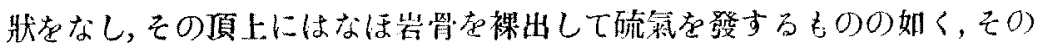

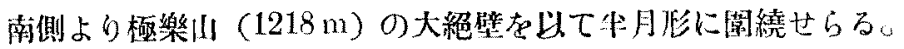

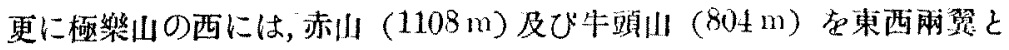

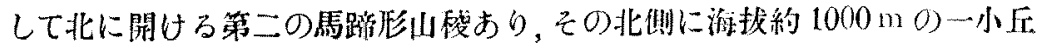
在擢し，その北侧になほ活動の餘勢在保つが如し。

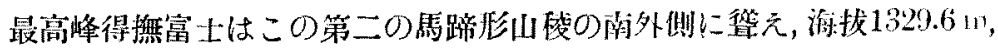

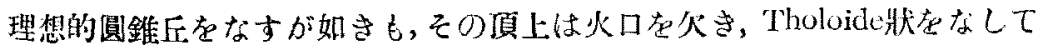

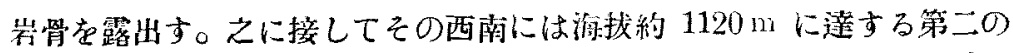
Tholoideと思はるっものおり。

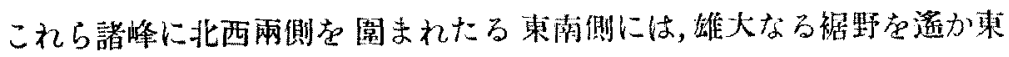
南に引ける大平山おり，その頂上には一大火口の殘壁と認むべき新月形の

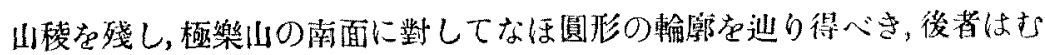
しろこの火口の北側に後より重なれるものなるへし。

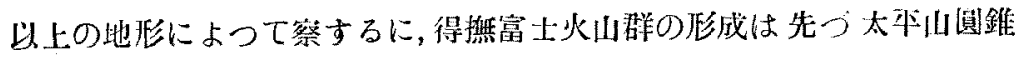
火山の成生に始まり，その頂上の爆發によつて Homate 狀を呈せる後，ての

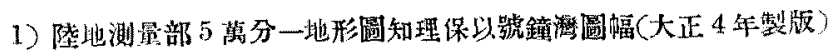


北西側及び北側に，二つの答生的火川を生じそれいは洪に一啳大なる高さ に達し。その北側在懪破して赥山一牛頍川及び極樂山の二つの馬路形環壁 と化し，最後にそれらの馬蹄形火口内上り，それぞれ一の鐘狀火山を噴出し

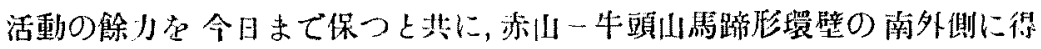
挴富士及び他の一の鐘狀火川在生ぜるものの如し。

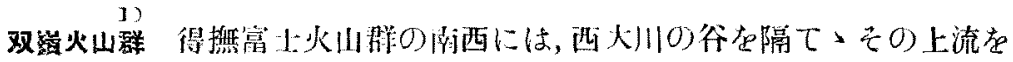

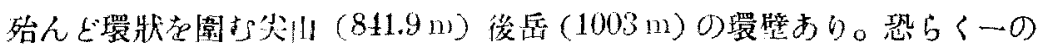
死火山なるぺし。

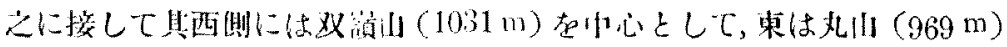

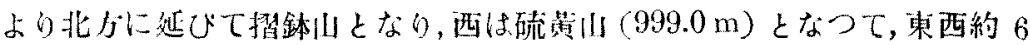

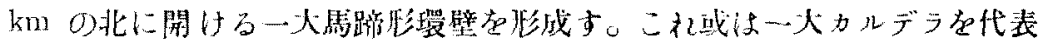

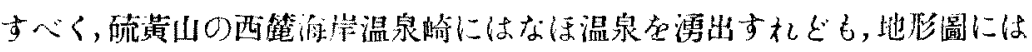
㖦氧孔の符號を留めず。

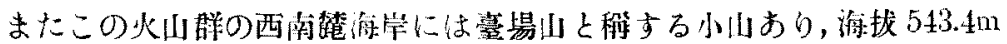

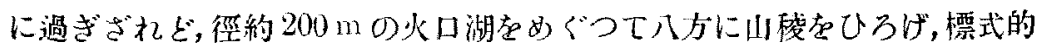
Homate 狀度な。

因に東京帝國大學編筑睍科年表には得撚島 $(1430 \mathrm{~m}) \sigma 1876$ 及 1894 年 に於ける活動を表示すれども，そのうち 1894 年(明治 27 年)に於けるも のは，恐らく日本噴火誌中に，根室海日新聞記事として揭げたる千島迴り 川䗁船の觀祭に基づくものなるべく，同船は同年 7 月 25 日成丹灣に缩泊 中，温泉崎の上手に區煙の上るを兒，柆朝砂の如き降灰を認め,進んてて 今萠の灣内に入りし時またもや爆吾を發して硫煙天を覆ふ在認めたりと 稱するも，噴火の地點明らかならず。同船は或は硫黃山の新噴火に非るか

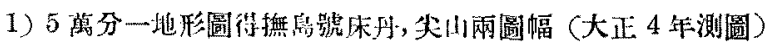

2) 震贸像防調查會報告第 86 號 285 頁。 


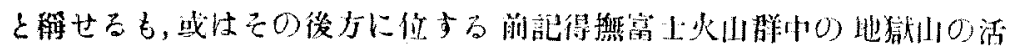

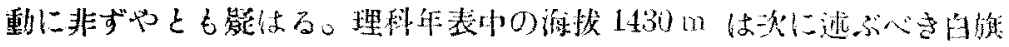

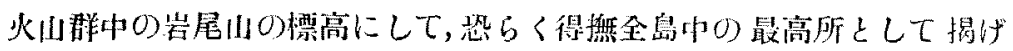
られたらしもその力向に於て前記の觀察に一致せず。

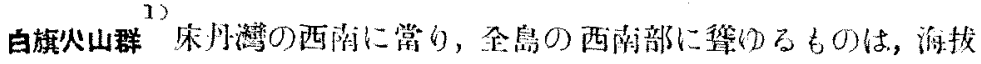

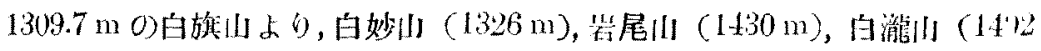

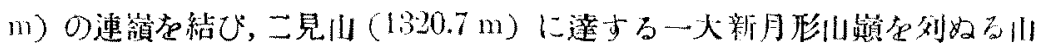

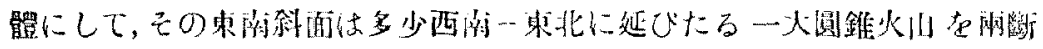

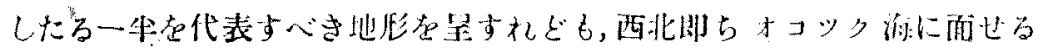

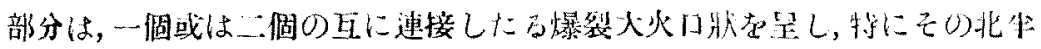

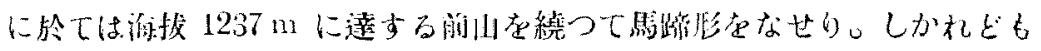

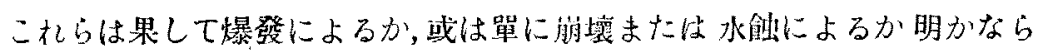

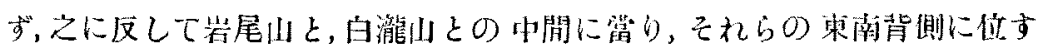

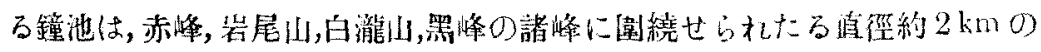
カルラ゙ラの一部に湛へたるものの如し。Snow の所謂 Faiwanobori-Kiliwanubori $(1113 \mathrm{~m})$ はこの何れかに相當すべし。

\section{II. 摆提島の火山}

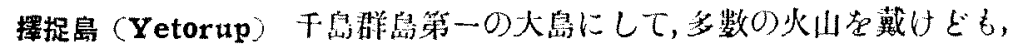

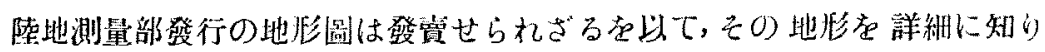
難くただ諸雜誌に散見する文献によつて之を稓し得るのみ。

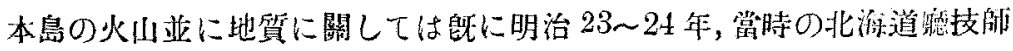
理學上利保小虎氏及び農學士石川貞治氏の調查あり，兩氏の報告によれ机，

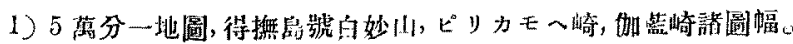

2) Wulf, Vulkanisms. Bd. 2 Teil. 1. Kあり。

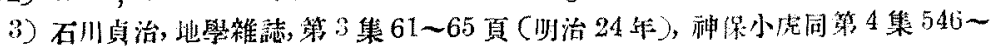
552 真 (时治 25 年)。 


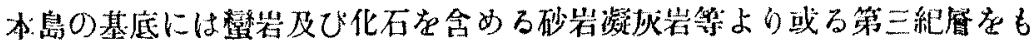
見れども，岛の大部分は火山岩より成り，次の諸火山数炣し。
(1) Moyoro
(2) Chirupnupuri,
(3) Shashoushinupuri
(4) Hechiranup
(5) Rebunshiri,
(6) Shitokap
(7) Atosanupuri
(8) Peretarabets

この外モロヨ岳の北には剖威岳一名安渡移矢獄むり，阿登侉登の南には 得茂别湖 (Urumobetsu) 湖在中心とするカルデラあり，その西方の萠消瀿 はた一のカルデラ中に消水を入れたるものとす。

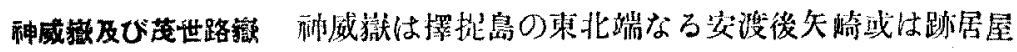

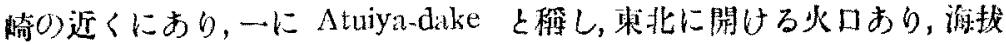
$1322.11 \mathrm{~m}$ に達す。

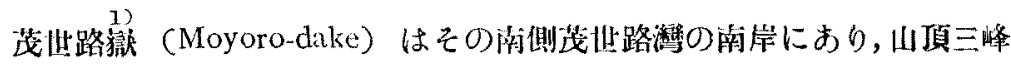

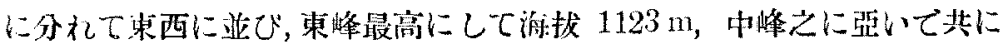
Tholoide 狀をなす，西峰はシュブチヤヌブりと积して，最も低く，西に開け る火口ありて, 硫黃在堆積す。本火山の南麓には更にホンヌプリの小丘わ り, 明治 16 年 2 月 29 日噴火せるものにして, 頂上に近く周圍約 $70 \mathrm{~m}$ の小

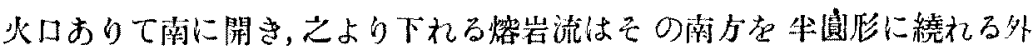
輪山下の湖畔に迋し，之考東西に分てりと程せらる。

因に明治 16 年 8 月 22 日朝野新聞紙上に於ける根室縣標津通信として東

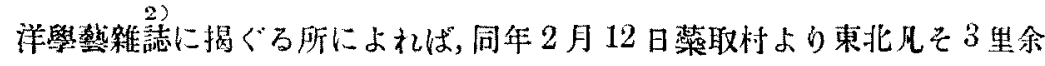

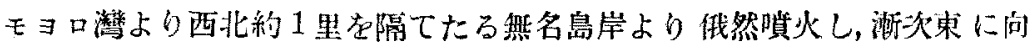

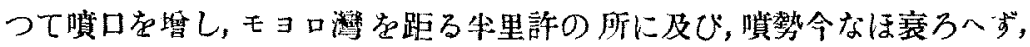
鳴動 10 里の外に達せりとあり。この噴火と,前記ボンスブリの活動との關

1) 石川貞治, 前出。

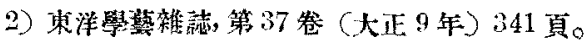




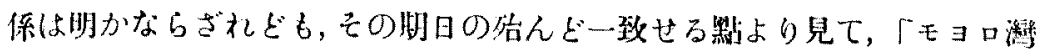
より西北」は東陶の詋ならむか。

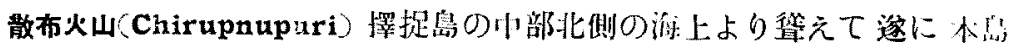

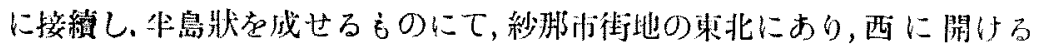

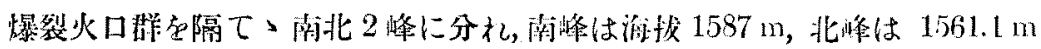

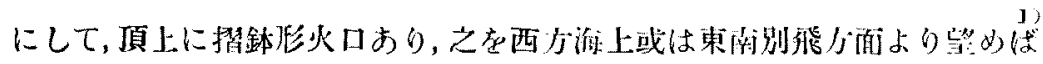

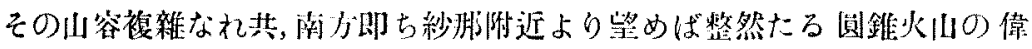
容を呈す。

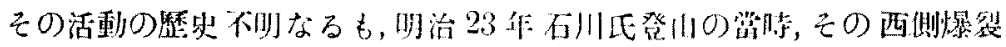

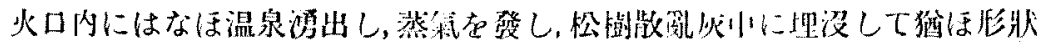
を估しその狀並に紗脚に於ける一土人の言に上れば,この爆發は當将を递 ること三十・作前に行なはれ九たりといふ。

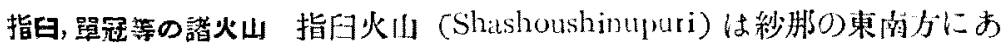

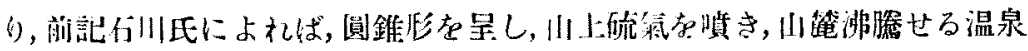

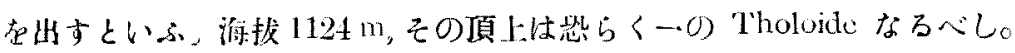
この火川の西南に近く，單筧淎の東北崖には，石川氏の記せるへチラヌッ ブ川おり，山點臼狀を呈し，全山㟔石にして淛づべからずと記さる。思ふに 一の Tholoide なるべし。この山と，小网萠山（1207 m) との關係は明ら かならず。或休同山罢名ならむか。

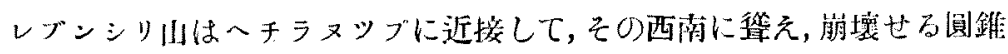

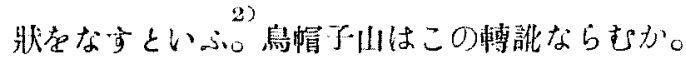

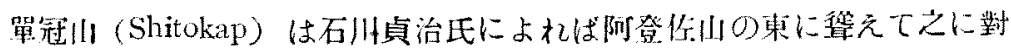
し, 高さ或は全島第一ならをと。本火山は東西二山に分れ，西單冠山は湖拢

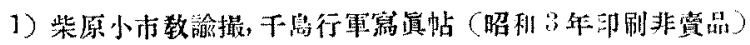

2) 神保小虎, 前出。 
$1565.8 \mathrm{~m}$. その頂上に數個の爆裂火口を有す。またその東の恩根登は海拔 $1426 \mathrm{~m}$ ，其に散枯登に瑟ぐ高さ在有す。

阿登传火山(Atosanupuri) 擇捉島南部西岸の良港内保㩐の北に保えて牛 島狀在なし，内保方面等より珡めば理想的 Konide 在なせり。前記石川氏 の記事に壉れれば，二個の二重火山なれども，外輪山は唯だ東側にのみ殘存し 全體として美しき圆錐形を呈しその頂上に南北約 $400 \mathrm{~m}$ 東西之に体する

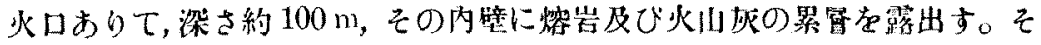
の南北雨端は缺開して。燃岩流出の阿戶在成す。最高點は火口壁の東側に あり,海拔 $1205 \mathrm{~m}$ なり。

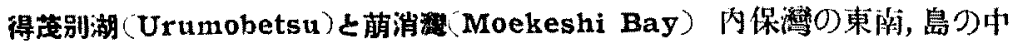
軸部には徑約 $3 \mathrm{~km}$ の得茂別湖あり,徑約 $18 \mathrm{~km}$ に橽する一大カルデラ壁 をめぐらし、その北壁っマホシリは最高 $671 \mathrm{~m}$ に達し、またその西壁にはオ ンアネヌブリ $(742 \mathrm{~m})$ の隆起あり。六州火山またこのカルデラの献に接 して西に開けるカルデラを有しそその南壁は最高 $770.7 \mathrm{~m}$ に達す。

萠消灣また徑 $8 \mathrm{~km}$ に達するカルデラにして，その北壁は缺壤して游に

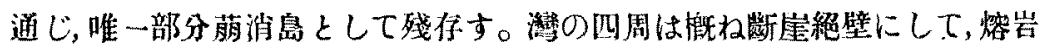

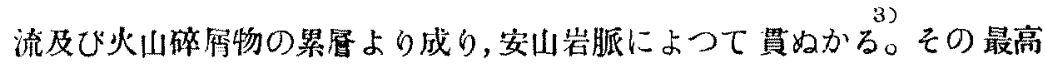
點は灣の南岸にありて，游拔 $40 \mathrm{~m}$ なり。

ベレタラベッ山は擇捉島の障西端に位し，游拔 $1221 \mathrm{~m}$, 西に開ける火口

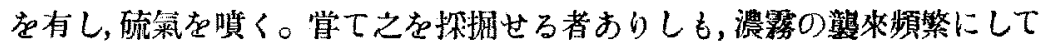
業を縝くるに耐えずと稱せらる。(未完)

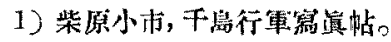

2) 石川貞治, 前出。

3) 石川貞治, 前出。 